\title{
KENT MEYDANI KAVRAMININ DEĞİŞEN ANLAMI VE İZMİT ÜÇYOL MEYDAN UYGULAMASI
}

\section{ÖZET}

İmit, M.Ö. 3.YY itibari ile yerleşik düzenli kent izlerinin gözlendiği, Kocaeli ilinin merkez ilçesi konumunda olan bir yerleşimdir. Coğrafi konumu, Marmara Denizi- İmit Körfezi kıyısında olup bin yıllardır önemli ticaret yollarının içinden geçtiği bu sebeple de büyük medeniyetlere ev sahipliği yapmış topraklardır. Ülkemizin yaşadığı sanayileşme sürecinde İstanbul'un komşu şehri olması ve denizyolu-demiryolu-karayolu-havayolu ulaşım imkânlarını barındırması nedeni ile tarihi birikiminin yanında sanayi ve ticaret kenti olarak da büyümeye devam eden yerleşim, artan insan ve taşıt trafiği sebebi ile kent alanlarında bazı yenileme ve düzenlemelere ihtiyaç duymaya başlamıştır. Bu çalışmada, söz edilen ihtiyaçlar çerçevesinde İzmit Belediyesi'nin talebi ile İzmit Bekirdere-Üçyol meydanı için tasarlanan ve daha sonra uygulanarak kullanıma açılan projenin, kent meydanı kavramının anlamsal değişimi bağlamında örnekler ile birlikte irdelenmesi yapılmaktadır.

Anahtar Kelimeler: Kent Meydanı, Tasarım, Mimarlık Kocaeli-İmit, Tarihi ve Kentsel Doku

\section{THE ALTERED MEANING OF THE CONCEPT OF THE CITY SQUARE AND İZMİT ÜÇYOL SQUARE IMPLEMENTATION}

\section{ABSTRACT}

Izmit is a settlement at which the traces of permanent urban settlement have been seen as of 3rd Century B.C. and which is in the position of the central district of Kocaeli province. It is geographically located at the coastline of Marmara Sea-İmit Gulf and the land through which the important trade routes pass, therefore hosted great civilizations. Being the adjacent city of İstanbul and has the seaway-highway opportunities, İmit, besides of its historical background, started to require some modifications and reorganizations on the urban areas due to settlement, increasing population and vehicle traffic because of the growth as an industrial city the in this industrialization process including our country. In this study, the project designed for the crossroads of İzmit Bekirdere-Üçyol, implemented later, and brought into service upon the demand of the municipality of İmit and within the scope of aforementioned requirements is discussed along with the concept of city square and examples.

Keywords: Town Square, Design, Architecture Kocaeli-İmit, Historical and Urban Texture 


\section{GİİŞ (INTRODUCTION)}

İlk yerleşik düzenlerden itibaren bulundukları kentin temel öğesi ve kent kültürünün bir parçası olan meydanlar, kentin kimliğinin ortaya konma aşamasında etkin rol almakta ve gündelik yaşamın alışveriş, dinlenme-eğlenme, ulaşım gibi faaliyetlerini ve önemli toplumsal olaylarını, açık-yarı kapalı-kapalı alanlarında barındırmaktadır.

Kentsel açık mekânların en etkin kullanılan parçalarından biri olan meydanlar, kentin kültürel, sosyal ve dini değerlerinin, güvenlik unsurlarının ve yönetim biçimlerinin etkisinde anlam, ifade gücü, ifade şekli, biçimlenişleri değişerek ve gelişerek varlıklarını geçmişten günümüze korumuşlardır. İlk düzenli yerleşimlerden günümüze kadar gelen süreçte kentleşmenin gelişme göstermesi ile sürekli bir anlam ve biçimleniş değişimi gözlenen meydanların gelişim ve değişim hızları ve süreçleri, inceleme alanı olarak seçilen medeniyetlerin beşiği Anadolu topraklarında ve yakınındaki Batı Avrupa'da farklı olmuştur.

Sınırlarına dâhil olan herkesi zorunlu olarak birer kullanıcı konumuna sokan kentler ve kentlerin yaşam merkezleri olarak anllan meydanlar, kentlilerin ya da değişik kullanıcılarının kültürel birikimlerini paylaştığı, aktardığı, tekrar öğrendiği yerlerdir. Aynı zamanda bir kentin tanımlanması yani o kente dair imaj oluşumu bağlamında kullanıcılarının; kültürel kimliklerini, kişisel gelişimlerini ve birbirleriyle etkileşimleri sonucu kentli olma deneyiminin elde edilmesi de bu mekânlarda olmaktadır (İnceoğlu, 2013:134). Kentsel yaşamın özellikleri kültürle değiştiğinden ve geliştiğinden yeni ihtiyaçlara cevap verebilecek farklı kentsel mekânlara gereksinim duyulmaktadır. Bu ihtiyaçların devinimi ile büyüyen ve değişen kentler farklı coğrafyalarda farklı etkilerle farklı kimliklere bürünmüşlerdir.

Bu çalışmada; yukarıda belirtilen yerlerdeki kültürel, sosyal, dini değerler ile yönetim biçimlerinin kentlerin odak noktaları olan ve kentin nabzını tutan meydanların biçimlenmesine ve anlam değiştirmesine etkileri örneklerle sorgulanarak karşılaştırmalar yapılmıştır. Bu sorgulamaya örneklem alan olarak İzmit Belediyesi'nin 15.10.2010 tarih ve 4063 sayılı yazısı ile Kocaeli Üniversitesi Mimarlık ve Tasarım Fakültesi'nden düzenlenmesini talep ettiği "Üçyol Meydanı" seçilmiştir. Bu meydana ilişkin yapılan mekansal sorgulamalar ve hazırlanan projenin temel tasarım kararları meydan kavramının anlamsal değişimi bağlamında anlatılacaktır.

\section{2. ÇALIŞMANIN ÖNEMI (RESEARCH SIGNIFICANCE)}

Çalışmada, yerleşik yaşam düzeninin başladığı zamanlardan günümüze kadar gelen süreçte kamusal mekânların odak noktası olarak nitelendirilen meydanların Anadolu ve Avrupa toprakları üzerindeki gelişim süreçleri ve bu süreçte etken olan faktörlerin meydanların biçimlenişindeki rolleri sorgulanmaktadır. Sözü edilen yerlerdeki günümüze kadar ulaşmış en bilinen kent meydanları inceleme altına alınarak meydan kavramı içinde algılanan temel öğeler tespit edilmektedir. Bu temel öğeler ışığında meydan kavramının günümüz küreselleşen ve sanayinin etkisiyle büyümeye devam eden kentlerde nasıl anlam değiştirdiği ortaya konması açısından çalışma önem arzetmektedir.

Bu çalışma için örnek alan, İzmit Bekirdere Üçyol Meydanıdır. Yerel yönetim ve Üniversite işbirliği ile tasarımı yapılmış ve uygulaması gerçekleştirilmiş olan bu proje; günümüz kent meydanlarının tasarım prensiplerindeki değişkenlerin ortaya çıkarılması, sanayileşmenin tetiklediği kentleşmenin etkisi ile plansız gelişen 
kentlerdeki meydan kavramının biçimsel değişmelerinin ve anlamsal boşalmalarının irdelenmesi açısından önem taşımaktadır.

\section{KAVRAM OLARAK MEYDAN VE TARİHSEL SÜREÇ İÇİNDEKİ GELİŞİMI (SQUARE AS A CONCEPT AND ITS DEVELOPMENT WITHIN HISTORICAL PROCESS)}

Meydan; mimari elemanlarla sınırları belirlenmiş, toplumsal işlevi olan ve kentin çekim noktası olarak kullanıcılarını kendisine çeken ve kullanıcıların her türlü gündelik ihtiyaçlarını karşılayabilen, kolay ulaşılan ve kente kolay dâhil olunabilen konumda bulunan bir kent parçasıdır. Meydana yönelen sokak bağlantıları konumu gereği sokak kullanımında olduğu gibi hızlı akışı değil, beklemeyi ve duraksamayı gerektirir ve kimi zaman sadece yaya trafiğine açıkken kimi zaman da araç ve yaya trafiğinin aynı zamanda kullanımına olanak sağlamaktadır. Böylece, kent içi yaya ve araç trafiğinin de yönlendirilmesi için ana ulaşım arteri konumunda olabilmektedirler.

İnsanoğlu iklim koşullarının daha elverişli hale gelmesi ile Neolotik Dönem'de (M.Ö. 8000-5500), doğayla olan ilişkisini kendi lehine çevirmeye başlamış, üretim ile gelen yerleşik yaşam ilk gruplaşmalarla birlikte köylerin ve giderek kentlerin oluşmasına imkân vermiştir. Böylece ilk meydanlar, açık meydan çevresinde evlerin gruplaşması sonucunda oluşmuş, dışarıdan gelebilecek saldırılara karşı maruz kalınacak yüzeyin azaltılması ve içsel kontrol sistemi bu sayede kurulabilmiştir (Vardar, 2005:30). Bu dönemin en planlı gelişen yerleşimlerinden biri olan Aşıklı Höyük'teki evler gruplar halinde tek, iki ya da üç gözlü olarak inşa edilirlerken aralarında sokak izlerine rastlanmıştır (Malkoç, 2006:188).

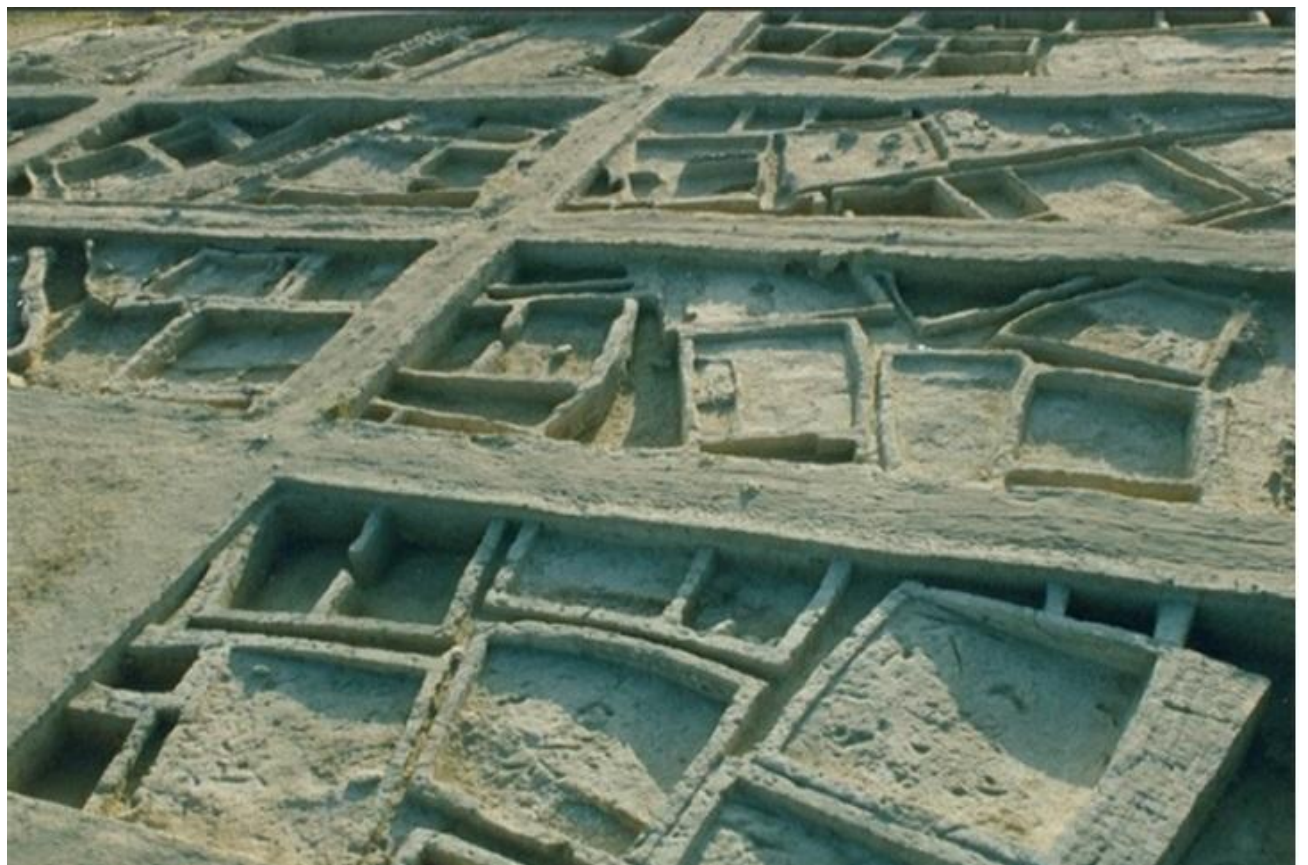

Resim 1. Aşıklı Höyük yerleşimindeki konutlar ve aralarındaki sokak izleri [9]

(Figure 1. Houses at Aşıklı Höyük settlement and street traces among them [9]

Anadolu'nun bugüne kadar rastlanan en eski ve en büyük Neolitik Dönem yerleşim merkezi olan Çatalhöyük'te ise 1000 kadar evde 5-6 bin kişinin yaşadığı bir kent dokusu vardır. Bu dönemde yer yer iç avlular 
oluşturularak içe dönük açık mekân kullanımlarının oluşturulduğu görülmüş, dönemin açık mekân kurgulamaları grup konutların açıldığı kent meydanları gibi içe dönük avlular ve tapınak çevrelerinde yer alan açık tapınma alanları olarak belirmiştir. Neolotik Dönem'in ardından gelen Kalkolitik Dönem'de (M.Ö. 5500-3000) yerleşimlerdeki biçimleniş ilerlemiş ve pazar yerleri ile birlikte kenti çevreleyen surlar görülmüştür. Eski Tunç çağında maden bakımından zengin olan Anadolu topraklarında yapılan madencilik ve madencilik ticareti, ticari yaşamı ve kentleşmeyi geliştirmiştir. Hitit Dönemine (M.Ö. 2000-700) gelindiğinde kent düzeninde daha büyük alanlar gözlenir ve ön avlulu yapılan saray yapıları ile açık mekanın biçimlenişine ilişkin ilk örnekler izlenebilir (Erdoğan, 1996:547).

Antik Yunan'da M.Ö. 500 yılından sonra gelişen akropolis ve sonrasında gelen agoralar yerleşimlerin odak noktası olarak konumlandırılmaktaydılar. İlk zamanlarda dinsel öğelerin konumlandırıldığı meydanlara daha sonra ekonomik ve toplumsal değerler de eklenmeye başlamış ve agoralar farklı fonksiyonları barındırmıştır. Birçok Yunan kentinde mevcut alanlar özelden çok genel kullanım için ayrılmış, demokrasinin gelişi ile kent yapısı içinde meydanlar oluşturulmuştur. Yunan kentlerindeki organik doku, oranlar ve insan ölçeğine dayalı mimari gelişim, iki katlı revaklar, aksiyel kompozisyonlar, anıtsal merdivenler; Romalılarda yerini daha büyük ölçeğe, daha boş hacimlere ve artistik duruşlara bırakmıştır (Dağıstanlı, 2007:12). Antik Yunan'da kent devletleri otonom merkezlerin birliği olarak örgütlenirken, Roma'da ise hüküm süren İmparatorluk sistemi merkezi yönetim nedeniyle ortaya çıkan bu iki farklı meydan yorumunun temelinde yönetim biçimi yatmaktadır.

Kentleşme tarihine bağlı olarak gelişimini sürdüren meydanların Batı'daki tarihsel geçmişine bakıldığında; Roma Imparatorluğu'nun 5. Yy.da doğu ve batı olarak ikiye ayrılması ile başlayan çöküşü Avrupa'da kentsel yaşamı sekteye uğratmıştır. Merkezi otorite ile yönetilen Roma İmparatorluğu'nun birleştirici gücü ortadan kalkınca başlayan Germen istilaları ile yolların ve kentlerin güvenliği kalmamıştır. İmparatorluğunun ekonomik ve politik sürekliliğini sağlayan güçlü yol ağı artık kentlerin istilasını kolaylaştırmakta, göç ve salgın hastalıklar ile yaşam sekteye uğramaktadır. Bu durum kent yaşamı için karanlık çă̆ın başlamasına neden olmuştur. Batı'da 9. yüzyıldan itibaren politik istikrar yeniden tesis edilirken, yerleşik hayat yeniden canlanmaya başlamış ve kentlerden çok manastır etrafında kümelenmiş köyler, dağınık kırsal yerleşmeler görülmüştür. Roma İmparatorluğunun birleştirici gücünü dini kurumlar yüklenmeye başlamıştır. 11. yüzyıla gelindiğinde kent surlarının daha dayanıklı yapılabilir olması kentleri daha güvenli kılmaya başladığından ekonomik canlılıkla birlikte kent yaşamı da canlanmaya başlamıştır. 12. ve 13. Yüzyıllar, Ortaçağ şehirciliğinin altın yılları olarak nitelendirilmekte ve günümüze ulaşan çoğu Batı Avrupa kentinin kuruluş dönemi bu yüzyıllara denk gelmektedir. Ticaretin gelişmesi ile üretimde başlayan çözülmeler, üretim-tüketim-ticaret sirkülâsyonunu hızlandırmış, bu durum tüccar sınıfının ortaya çıkmasına neden olmuştur. Zamanla yükselen tüccar sınıfı, kendi içinde uzmanlaşmakla beraber hareket alanlarını genişletmek ve özerklik elde etmek için "belediye" örgütlerini kurmuşlardır. Böylece, kilise-lonca ve belediye kentin önemli kurumları olarak belirginleşirlerken, bu kurumlara ait yapılar, kentin önemli parçalarından biri olan meydanlardaki yerlerini almışlardır. Bu duruma örnek olarak gösterilebilecek $102 \mathrm{~m}$. boyundaki çan kulesi ile İtalya'da inşa edilmiş ikinci büyük ortaçă̆ kulesi olan ve bulunduğu meydana simgesel değer katan Palazzo Pubblico (Belediye Binası), Siena'da, Piazza Del Campo' (Del Campo Meydanı)dadır. 


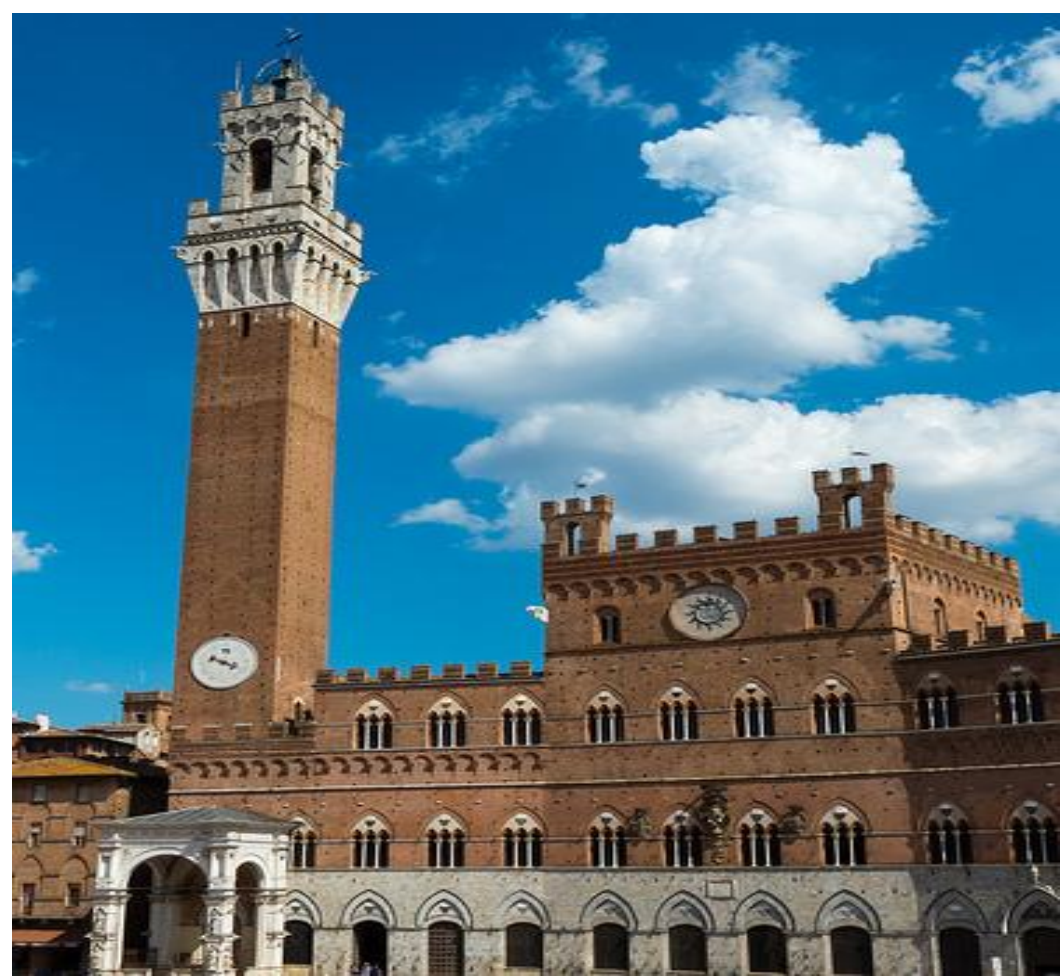

Resim 2. Avrupa'nın en büyük meydanlarından biri "Piazza Del Campo"nun 1342 yılında tamamlanan belediye binası ve çan kulesi [16]

(Figure 2. The municipal building and bell tower completed in 1342 at "Piazza Del Campo", one of the biggest squares of Europe [16]

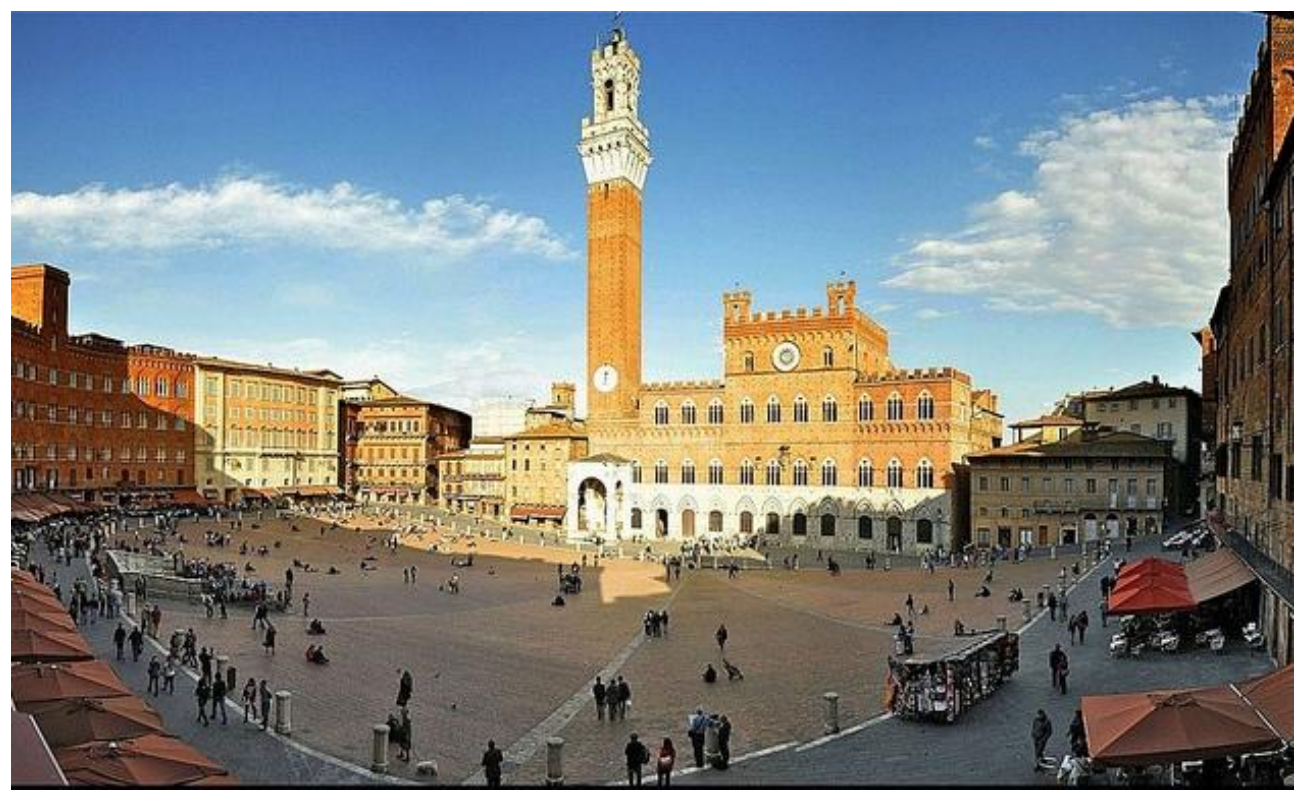

Resim 3. "Piazza Del Campo", Gotik üsluptaki Belediye Sarayı başta olmak üzere pek çok önemıi yapı ile sınırları çizilmiş bir meydandır [16]

(Figure 3. "Piazza Del Campo" is a square the borders of which are drawn with many significant buildings, particularly the Town Hall in Gothic style [16] 


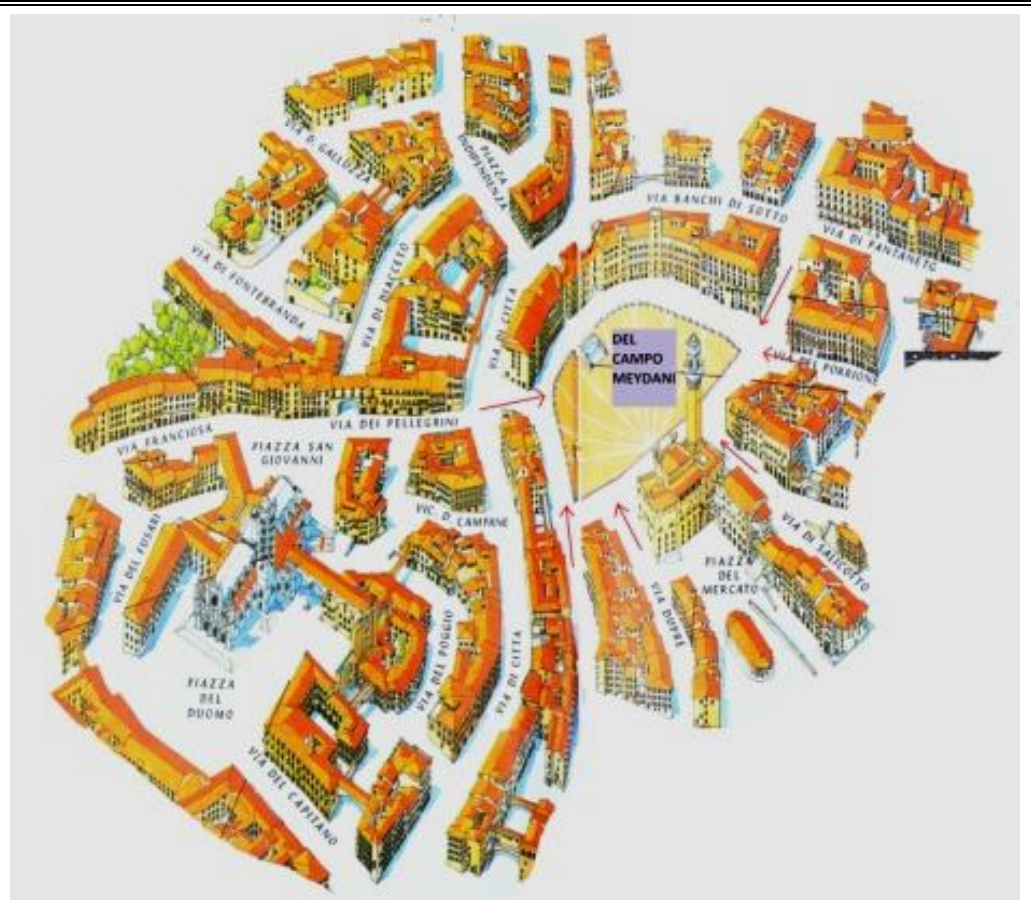

Resim 4. Del Campo Meydanını çevreleyen yapılar ve meydan ile sokak girişleri ile olan ilişkileri gösterir sunum [17]

(Figure 4. The presentation displaying the buildings surrounding the Del Campo square and the connections between the square and the street entrances [17]

Eski Roma forumunun bulunduğu yere kurulan bu meydanın geçmişinde büyük pazarların kurulduğu bilinmektedir. 1293 yılında Siena'nın yönetimini elinde tutan Dokuzlar Konseyi şehri büyütmek istediğinde meydan bugünkü şeklini almaya başlamıştır. Meydan zemininde döşeli olan dokuz parçalı tuğla zemin yönetimde etkin olan konseyin gücünü simgelemektedir. Meydanda bulunan çeşme, aktif olarak çalışmakta ve yaşı 5 asrı aşkın su kemerleri ile çeşmenin suyu taşınmaktadır. Günümüzde meydan etkin olarak kullanılmaktadır. Meydan kafeterya, turistik eşya mağazaları, restoran ve saraylarla çevrelenmektedir. Meydanda her yıl düzenlenen festivallerin (Palio) kökeni kayıtlarda 1283 yılı olarak belirtilse de, Roma Dönemine dayandığı bilinmektedir.

Diğer bir örnek ise 16. YY'da zemin döşemesi ve merdivenleri Papa III. Paulus Farnese'nin Michelangelo'ya hazırlattığı Roma'daki "Piazza del Campidoglio (Del Campidoglio Meydanı)"dır. Meydan şimdilerde müze yapısı olarak hizmet veren Rönesans dönemimin sarayları olan Palazzo Nuova ve Palazzo dei Conservatori ile sınırlandırılmıştır. Rönesans tarzında yapılmış olan şehir meclisi de (Palazzo del Campidoglio) Tabularium yıkıntıları üzerine kurulmuştur. Simgesel olarak meydanda bulunan küçük bir havuz heykeller ile desteklenmektedir. Şehir içi yaya yollarının kesişme noktası olarak yorumlanan bu meydan bir önceki örnekte de olduğu gibi anıtsal büyüklükteki yapıların izlenebileceği bir açıklık içermekte ve kullanıcılarını kucaklamaktadır. 


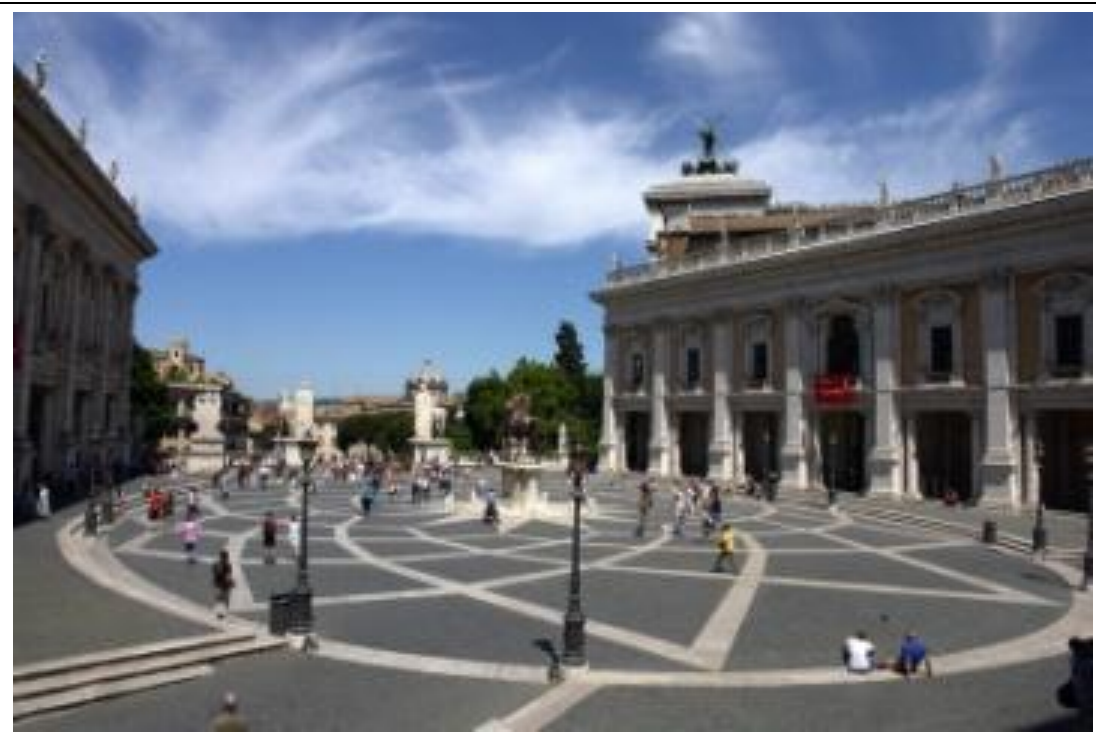

Resim 4. Tasarımını Michelangelo'nun 1536'da yaptığı Piazza del

Campidoglio, İtalya [10]

(Figure 5. Piazza del Campidoglio in Italy, designed by Michelangelo in 1536 [10]

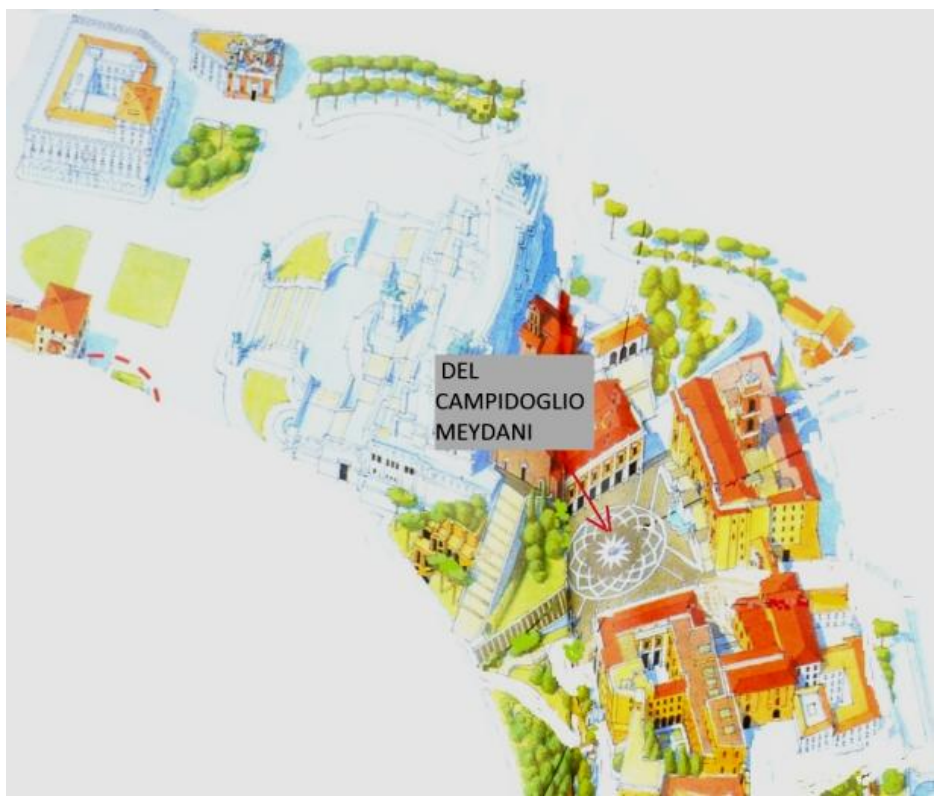

Resim 5. Del Campidoglio meydanını çevreleyen anıtsal yapılar ve merdivenler ile durumunu gösterir sunum [17]

(Figure 6. The presentation displaying the condition with monumental structures and stairs surrounding the Del Campidoglio square [17]

Fransa'dan bir 17. YY örneği olan "Neuf-Brisach iç kalesi" savunma amaçlı olarak bir askeri mimar olan Vauban tarafından (16981707) inşa edilmiştir. Birbirine eşit 48 kare meydanı çevreleyen simetrik kuleleri ile yıldız şekilli düzenlemeye sahiptir. Kalenin savunma amaçlı olarak düz yapılmış sokakları "Place d'armes" denilen merkezdeki yine kare formundaki tören alanına varmaktadır. Bu meydan yapılma amacından dolayı Batı Avrupa'nın alışıla gelmiş meydan kurgularından farklı olmasına rağmen sokakların birleştiği bir meydan kurgusu açısından ve ana meydandaki merkezi duruşu tamamlamak için kullanılmış havuz ile benzerlik taşımaktadır. 


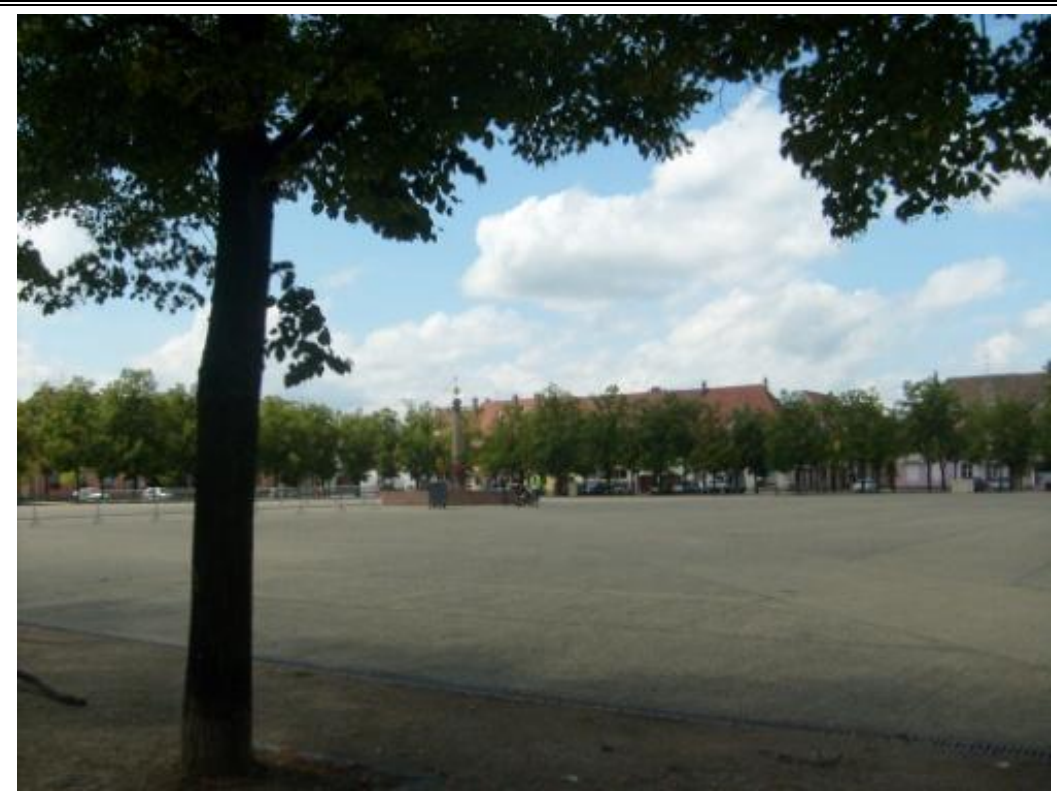

Resim 6. Fransa'dan bir 17. Yy. örneği olan Almanya sınırına yakın"Neuf- Brisach iç kalesinin tam ortasında bulunan ana meydan.

Yerleşimi çevreleyen surlar sebebi ile kale hiçbir zaman ele geçirilememiştir [11]

(Figure 7. The main square located in the middle of Neuf-Brisach citadel near German border and which is a 17th Century example from France. The castle has never been conquered due to the ramparts surrounding the settlement [11]

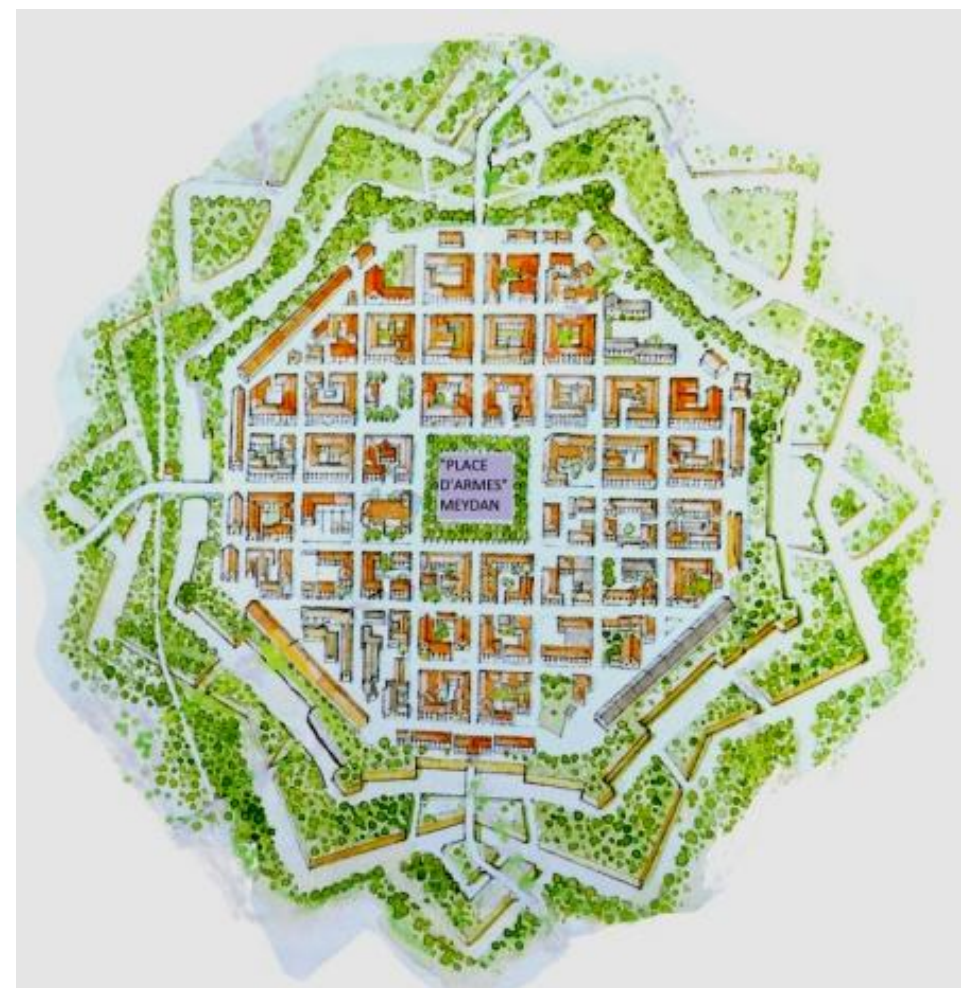

Resim 7. Neuf- Brisach iç kalesinin sokak ve meydan ilişkilerini gösterir sunum [17]

(Figure 8. The presentation displaying the connections of Neuf-Brisach citadel with the square and the streets [17] 
Coğrafi olarak ülkemize yakınlığı sebebi ile her türlü gelişimini doğuya oranla daha çok ve daha rahat izlediğimiz Batı Avrupa'da 12. ve 13. yüzyıllar itibari ile yaygınlaşan kentleşme faaliyetlerinin bir sonucu olan kamusal alanlardan meydanların çoğunun temelde aynı, özelde farklılaşan izlerle günümüz kullanıcılarına hizmet verdikleri gözlenmektedir. Incelenen konuya ilişkin tarihsel geçmiş izleri daha belirgin olan, peysaj mimarisinin de ön planda olduğu ve mutlak monarşi ile yönetilen Fransa'nın; 1605'de IV.Henry tarafından yaptırılan "Place des Vosges", Fransiz Devrimi'nin izlerini barındıran "Place de la Bastille", 18. yy. saray yapıları ile çevrili "Palace de la Bourse", Avrupa'nın en görkemli meydanlarından biri olarak kabul edilen tarih boyunca kanlı olaylara sahne olmuş ve ismi şu anda "Place de la Concorde" olarak anılan meydan, kestane ağaçları ile üç kenarı çevrili ve yapımı altı farklı mimar ile 140 yılda tamamlanan kilise ile dördüncü ayrıtı tanımlanan "Place St-Suppice", yapımına kraliyet meydanı olarak 1698 yılında Mimar Jules Hardouin-Mansart tarafından başlanan "Place Vendome" meydanı örnek olarak gösterilebilir.

Italya meydanları, Fransa'ya oranla konu hakkında daha zengin duruş sergilemektedir. Bu meydanlara örnek olarak; Pisa Üniversitesi'nin (1562) Scoula Normale Superiore bölüm binasını barındıran "Piazza dei Cavalieri", Bologna'da revaklı yapılarla çevrili "Piazza Cavaur", 12. ve 13 yüzyıllarda yapılmış 13 kulesi ile farklı bir silueti olan San Gimignano'nun merkezindeki "Piazza Della Cisterna", Roma 'da Pantheon'un hemen arkasında bulunan "Piazza della Minerva", yine Roma'da üç muhteşem Barok çeşmenin bulunduğu ve kafeteryalarla çevrili "Piazza Navona", 19. YY'da yapılmış Floransa'nın en eski kafeteryaları ile çevrili "Piazza della Republica", Napolyon'un Avrupa'nın en güzel salonu olarak nitelendirdiği Venedik'teki "Piazza San Marco" meydanı örnek gösterilebilir.

Fransa'daki peysaj mimarisinin ön planda olduğu izlenen meydanlara İngiltere'den bir örnek de, yaya ve araç trafiğine açık yollarla çevrilmiş "Trafalgar Meydanı"dır.

Tüm bu örnekler incelendiğinde bu dönem meydanlarının biçimlenmesindeki ve içerdikleri anlamlardaki değişikliklere sebep olan etkin faktörler ve genel karakteristik özellikleri başlıklar altında toplanabilmektedir. Bunlar;

- Anıtsal nitelikte bir ya da birkaç yapının meydanın sınırlarını oluşturduğu,

- Bu yapıların zamanının dini yapısı, idari yapısı ya da idareden sorumlu saray yapısının olduğu,

- Bazı meydan sınırlarının tamamlanması için ulu ağaçların kullanıldığı,

- Çok büyük heykeller ile desteklenmiş büyük süs havuzlarının, heykellerin, su kuyularının ya da dikilitaşların meydanlardaki merkezileşmeye destek sağladığı,

- Mekânın tanımlanmasına destek olan yer döşemelerinin dahi, meydan sınırlarını belli eden yapılar gibi tasarlanarak uygulamasının yapıldığı,

- Bazı meydanların sadece yaya ve acil durum trafiğine açık olduğu,

- Eğlenme-dinlenme ve rekreasyon amaçlı olarak meydanların kullanıldığı,

- Meydanların gündelik yaşam ihtiyaçlarına hizmet ettiği, buna ek olarak festivaller gibi toplumsal olaylara mekân olduğu, 
- Yapı ve meydan boyutlarının insan boyutlarına oranla çok büyük olduğu,

- Görkem ve simetrinin tek yöneticili toplum yönetiminin güçlerini simgelemek amacı ile kullanıldığı ve yol akslarının yönetici konutunda kesiştirildiği,

- Yapım kararlarının dönemin ileri gelenleri ya da yöneticileri tarafından verilmiş ve tasarımları da zamanın konu ile ilgili kişilerine yaptırılmış olması,

- Yapıldıkları tarih ve günümüze ulaşmış olmaları sebebi ile bulundukları kentin tüm kültürel ve sosyal izlerini günümüze taşımaları izlenebilmektedir.

Ortaçă̆ döneminde özellikle Anadolu'daki Osmanlı topraklarındaki imar faaliyetlerine ve kentleşme düzenine bakıldığında, izlenen meydan oluşumları yol keşişim noktalarındaki geniş mekânlar olarak gelişmişlerdir. Yerleşim içindeki konumlanışları ve sosyal hayattaki yerleri açısından Batı Avrupa'daki aynı dönemlerde yapılan meydanlar ile geleneksel Türk mimarisindeki meydanların genel kurguları "meydan" adı ile aynı başlık altına alınsalar dahi; kültürel, sosyal, ekonomik, coğrafik özellikleri, boyutları, yapılışlarındaki tesadüfîlikkendinden oluşluk-düşünülmüşlük durumu, yönlendirmeler, yönetimsel gücü ve kültürel değerleri aktarma şekli, kullanılan temel öğelerin çeşitliliği dinsel faktörler gibi nedenlerden dolayı alt başlıklarda birbirlerinden tamamen farklı bir tutum izlemektedirler.

$\mathrm{Bu}$ farklı tutuma ilk sebep olarak Osmanlı Dönemi dış mekânlarında yaya ulaşımının esas alınması gösterilebilir. Genelde dar, dolambaçlı, yokuş hatta basamaklı sokak düzeninin görüldüğü, örneğine başka geleneksel kent dokularında az rastlanan çıkmaz sokaklar da yaya ulaşımının yaygın olarak düşünülmüş olmasının bir göstergesidir. Bir sokağın güvenliğinin ve mahremiyetinin genel kurgu öğeleri de düşünülerek "çıkmaz" olarak konumlandırılması dini ve sosyo-kültürel değerlerin de bir sonucudur. Bu dolaşım ağının bir parçası olan ve kamusal mekânlardan meydanların Anadolu topraklarındaki Osmanlı kentlerinde izlenen meydan oluşumları iki farklı şekilde biçimlenmiştir. İlki; daha çok rastlanan "küçük ölçekli meydanlar"dır. Sokakların kesişme noktalarındaki genişlemelerin organize edilmesi ile oluşan bu meydanların temel öğeleri ulu ağaç, çeşme, cami-namazgâh-mescit ve pazar alanları ve sonraki dönemlerde kurguya eklemlenen kahvehanelerdir. Bu mekânlar, mahalle ya da köy ölçeğinde hizmet verirler ve "köy meydanı" olarak anılırlar. Büyük camilerin avluları da kimi yerleşimlerde meydan işlevini görmüşlerdir. Diğeri ise; kent ölçeğinde hizmet veren büyük ölçekli meydanlardır. Bu meydanlar çeşitli spor aktiviteleri ve sosyal faaliyetlerin de gerçekleştirildiği, biçimsel bir kurguya bağlı olmayan, yerleşim dokusunun dışındadırlar. Sultanahmet Meydanı gibi Osmanlı kentlerinde daha önceki medeniyetlerden miras kalan meydan oluşumları da kökenleri itibari ile anlatılan bu iki meydan oluşumundan farklı bir konumdadır. Cumhuriyet döneminden sonra geleneksel dokunun; kimi zaman içinde, kimi zaman dışında ya da yakınında başlayan kentleşme faaliyetıeri ve kara ulaşım ağlarının kurulması ile yeni anlamlar yüklenmiş kent meydanları oluşmaya, tasarlanmaya başlanmıştır.

Avrupa'ya oranla ivmesi çok yüksek olarak hissedilen ülkemizdeki kentleşme sürecinde "kent meydanı ve işlevi" önceleri; hükümet binaları önünde tören meydanları, farklı yönlerden gelen taşıtları yollarına sevk etmek üzere planlanan trafik meydanları, yerel yönetime denetim kolaylığı sağlamak amacı ile yapılmasını desteklediği süreli ya da sürekli pazar meydanları ve dini yapılar önünde halkın birikim durumunu karşılamak amacı ile avlularının önüne yapılan meydanlar olarak tanımlanmışlardır. Bu özellikleri içeren ve 02.09 .2005 tarihli 
Hürriyet Gazetesinin yayımladığı "Türkiye'nin en güzel on meydanı" konulu yazısına bakıldığında da, hepsinin Cumhuriyetin ilk yıllarında yapılan ve zaman içerisinde yerel yönetimlerin ve siyasi erkin etkisi ile pek çok değişikliğe uğrayarak çalışmada örnek olarak sunulan diğer meydanlara kıyasla yapıldıkları yıllardan itibaren çok fazla biçimsel ve anlamsal değişikliğe uğradıkları görülmektedir. Günümüzde ise, ülkemiz kent meydanların ticaret yoğunluklu olarak görünüm kazandıkları izlenmektedir. Plansız ve kontrolsüz kentleşme ve kentlerin almak zorunda kaldıkları göçlerin fazlalığı ile tasarlanan ya da kendiliğinden oluşmuş meydanların alanları bir süre sonra yetersiz kalmaya başlamış ve bazı sosyal etkinliklerin spor alanları gibi özel tesislere aktarılması ile "meydan" anlamı biraz boşaltılmış, biraz da değiştirilmiştir.

\section{MEYDAN KAVRAMININ ANLAMSAL DEĞIŞIMIINDE ÖRNEK ALAN: İZMIT ÜÇYOL MEYDAN DÜZENLEME PROJESİ (SAMPLE AREA FOR THE MEANING CHANGE OF SQUARE CONCEPT: İMIT ÜÇYOL SQUARE ORGANIZATION PROJECT)}

Meydan kavramının yıllar içerisindeki bu anlamsal ve biçimsel değişimine rağmen son yıllarda Kocaeli dâhil sanayinin etkisi ile gelişmekte olan pek çok kentte kent mekânlarının düzenlenmesindeki ana aktör olan yerel yönetimin anlayışı değişmeye başlamış ve yönettikleri kentte kimlik kazandıracak ve kentsel yaşam kalitesini yükseltecek meydan projeleri üretilmeye ve uygulanmaya başlamıştır.

Bu projelerden biri Kocaeli İzmit Üçyol Meydan uygulamasıdır. Bu uygulama, bugün meydan olarak anılan bir alanın düzenlenmesini içermekle beraber aslında bu çalışmanın başından itibaren anlatılan meydan kavramının anlamının ne derece değiştiğinin ve günün genel geçer beğeni ve zorunlulukları kapsamında bir meydan tasarımı kavramının ne anlamda yorumlandığının ortaya konması açısından önem taşımaktadır. İzmit Belediyesi'nin 15.10.2010 tarih ve 4063 sayılı yazısı ile Kocaeli Üniversitesi Mimarlık ve Tasarım Fakültesi'nden alanın yeniden düzenlenmesi talebinde bulunması ile araştırma ve tasarım süreci başlamıştır. Çalışmanın araştırma süreci, kentin ve çalışma yapılacak semtin geçmişlerine ilişkin izlerini araştırma çalışmaları ile başlamıştır.

İzmit Yerleşimi'nin tarihi geçmişine bakıldığında ilk kent yerleşiminin M.Ö. 262'de Bityhinia Kralı Nikomed tarafından kurulduğu bilinmektedir. M.Ö. III. Nikomed döneminde Roma İmparatorluğu'na bağlanmış ve konumundaki bu değişiklikten sonra devlet kurgusu altında gelişimine devam etmiştir (Kaya, 2007:60-61). Coğrafi konumu gereği her zaman önemli bir şehir olarak görüldüğü için gelişimine aralıksız devam eden yerleşim, 1337'de Türk hâkimiyetine geçmiş, 1402'deki Timur ile yapılan Ankara Savaşı'na değin refah içinde yaşanan bir yerleşim olmuştur.

Osmanlı Devleti zamanında da bulunduğu konum itibari ile önemli sancaklardan biri olan İzmit, çöküş döneminde Kafkaslardan ve Balkanlardan en çok göç alan ilerden olmuş ve sancak iskân sınırları genişletilerek yeni yerleşim alanları açılmaya başlamıştır. 1857-18661879'daki göçlerle (Ulugün, 2012) açılan yeni yerleşim alanlarından biri olan Üçyol alanı, tarihi kaynaklarda "Bekirdere" olarak anılmaktadır. Yerleşimin başladığı ilk yıllardan itibaren bünyesinde kurulan birlikte un değirmeni, 1972'ye kadar faaliyetini Hoca Sokak'ta sürdüren cam fabrikası, tütün fabrikası, bakkallar, çay bahçeleri gibi ticarete yönelik faaliyetler önem kazanmaya başlamış ve yolların kesiştiği bu alan yaya odaklı bir ticaret bölgesine dönüşmüştür.

1950'li yıllardan itibaren ülkemizde sanayileşme politikasının ön plana çıkması, sanayinin büyük ölçüde Kocaeli’nde konumlanması, 
ilin İstanbul'daki OSB'lere yakınlığı, il planlanmasının bitmeden uygulama alanlarının açılması, sanayi odaklı göçler ilin diğer yerleşimlerinde olduğu gibi İzmit merkez yerleşiminin de plansız bir şekilde ve Batı Avrupa'daki kentlerden çok farkıı bir çizgide tarihinden koparak ve sanattan uzak kalarak büyümesine yol açmıştır. Bu hızlı ve plansız gelişen durum, kent meydanlarının bazılarının yol kesişmelerinin tanımladığı kavşaklardan türemesine sebep olmuştur.

İzmit merkez yerleşimi özelinde kentsel yerleşim ölçütlerine bakıldığında; meydanların daha çok kıyıya paralel giden ulaşım akslarının kesiştiği kavşaklar üzerinde konumlandığı, ticari faaliyetlerin yoğunlaştığı, yönetim ve dinsel yapılarla bütünleşmiş yaya ağırlıklı alanlar şeklinde belirginleşen meydan kavramının ulaşım araçlarının ön plana alındığı kavşaklar olarak uygulandığı izlenmektedir.

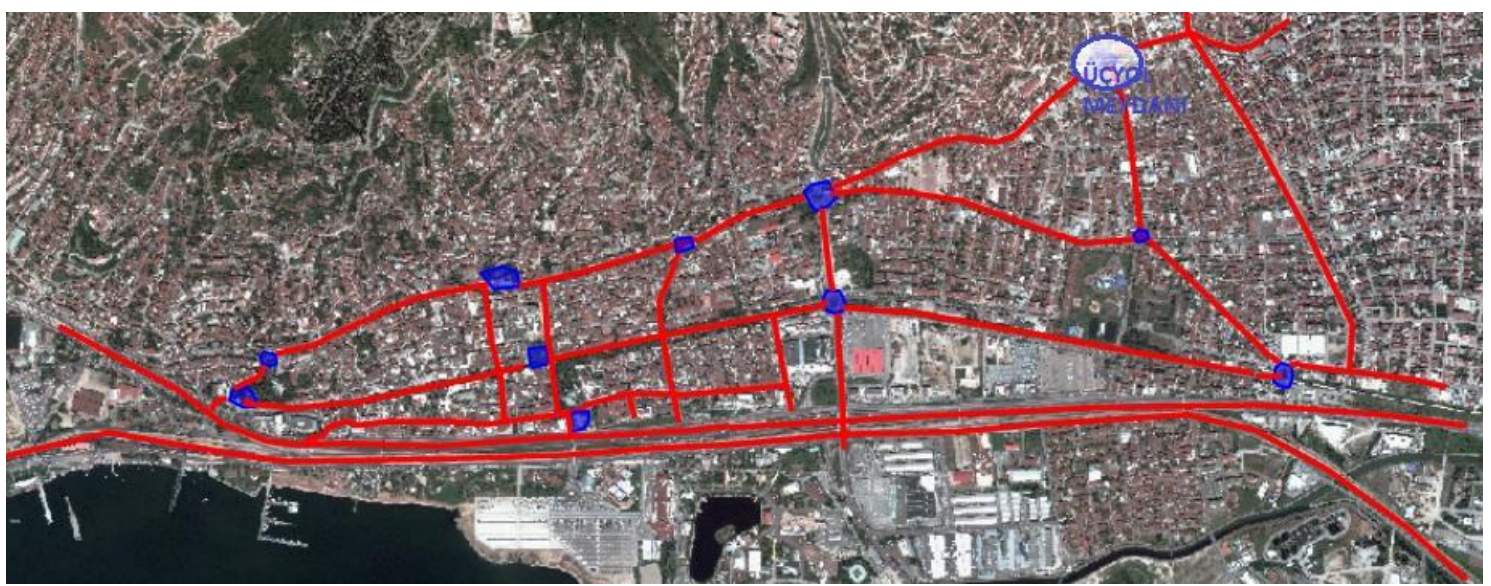

Harita 1. İzmit'in merkezinde kıyıya paralel gelişmiş yol güzergâhları, bu yolların kesişim noktaları olan kavşaklardaki kavşak/meydan ve park/meydan uygulamaları içinde Üçyol meydanının konumu [6]

(Map 1. Routes developed in parallel to coastline in the center of Izmit, the location of Üçyol square within the crossroad/square and park/square applications which are the junction points of these routes [6]

Üçyol Meydanı, 2000'li yıllara gelindiğinde; meydan sınırlarının düzensiz ve plansız yapılan bitişik nizam yapı blokları ile belirlendiği, blokların alt katlarının gündelik yaşamın her türlü ihtiyacına hizmet eden ticaret hacimleri, üst katlarının ise konut olarak kullanllan birimler olarak değerlendirildiği görülmektedir. Gündelik yaşama ilişkin gereksinimlerin karşılandığı dükkânların kullanıcıları olan yayalar, semtin hızlı akan ve kısa süreli park eden trafiği ile iç içe bir durumdadır. Bu duruma sebep veren yaya kaldırımlarının yetersiz genişlikleridir. Yetersiz olan bu kaldırım genişlikleri içerisinde yaya kullanıcıların ihtiyacı olan kent mobilyaları doğru ve yeterli düzeyde kullanılmadığı gibi kaldırım alanlarının büyük bir kısmı dükkânların sergi alanı olarak işgal altındadır. Atatürk Heykeli'nin yolların kesişme noktasındaki adada konumlandırılması sebebi ile meydan, tören alanı olarak da kullanılmaktadır. 


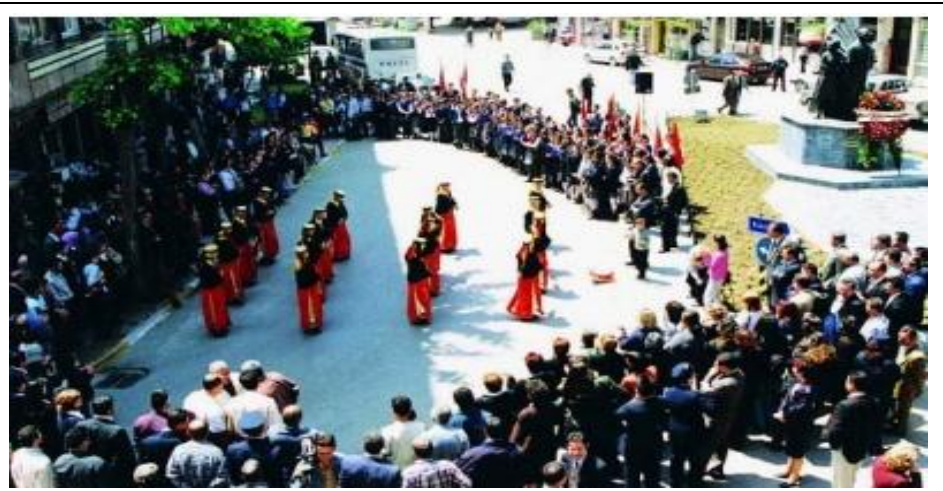

Resim 8. Projenin uygulaması yapılmadan önce Üçyol meydanında yapılan

bir resmi tören ve Atatürk heykelinin bulunduğu alanın durumu [14]

(Figure 9. A formal ceremony at the Üçyol square before the application of the project and situation of the area where the Atatürk statue stands [14]

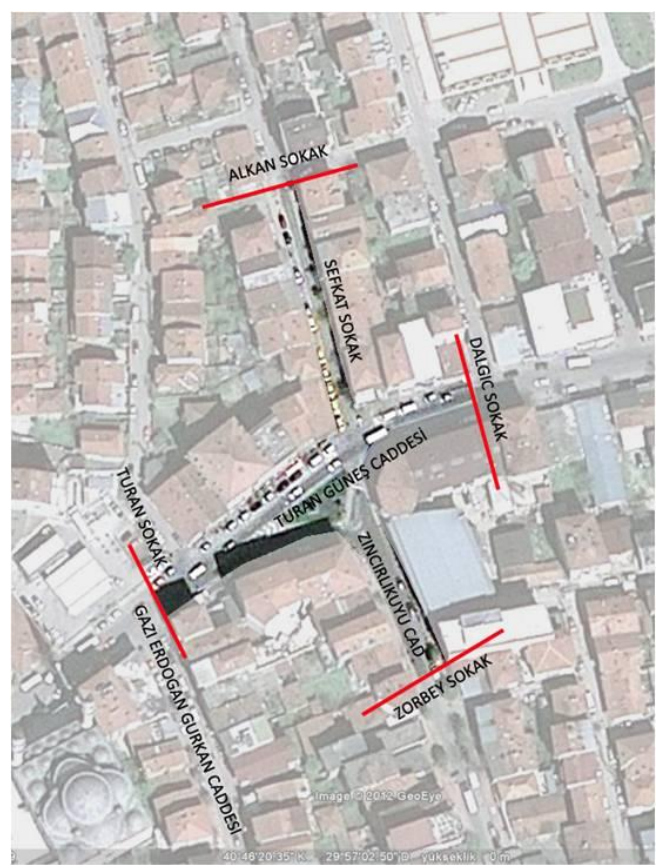

Harita 2. Projenin uygulaması yapılmadan önce alanın sınırlarını ve yapı durumlarını gösterir vaziyet planı [17]

(Map 2. A layout plan displaying the borders of the area and structure conditions before the application of the Project [17]

İzmit'te meydan olarak tanımlanan yol kesişmelerinden oluşan bu alanlardan biri olan Üçyol Kavşak - Meydan projelendirme çalışmasına ilişkin yapılan tarih araştırmalarından sonra mekânsal analizleri içeren kültürel, sosyal, ticari, kullanım alışkanlıkları üzerinden yapılan veri toplama çalışmaları ve tespit edilen sorunlar ve bu sorunlara ilişkin çözüm tespitleri;

- Araç trafiğinin artması ile alan için önemli bir faktör olmasına rağmen zaman içinde ikinci plana itilen yaya trafiğinin konforlu hale getirilmesi,

- Araç trafiğinin hızının ara sokaklarda ve meydan olarak tanımlanan sınırların içerisinde kontrol altına alınması, uygun döşeme kaplaması seçimi ile hız sınırlamasının yapılması, 
- Günümüz kent kullanıcısının kent alanlarında kullandığı kent mobilyalarına ilişkin doğru yerlerde ergonomik çözümlerin üretilmesi,

- Günümüz kent kullanıcısı için görsel zenginliğin sağlanması ve rekreatif alanların yaratılması,

- Hızlı kentleşmenin getirdiği plansız yapılaşma ile ortaya çıkan binalar ve cephelerindeki tabelaların oluşturduğu görüntü kirliliğinin önüne geçilmesi,

- Alanin ortasinda bulunan ve alani tanimlamaya destek veren Atatürk Heykeli'nin görünürlüğünün arttırılması, tören zamanları için bulunduğu alanın daha kullanışlı duruma getirilmesi,

- Kullanıcıya bir meydan alanına geldiğinin görsel olarak hissettirilmesi,

- Meydana çıkan ve yaya odaklı olarak etkin kullanımı olan Şevkat Sokak'ın yayaların kullanımında yaşanan sorunlar sebebi ile aktif araç trafiğine kapatılarak yayalaştırılması,

- Yapı cephelerinin yıpranmış ve görüntü kirliliği yaratan durumlarının kullanıcı üzerinde yarattığı olumsuz etkilerinin önüne geçilmesi şeklinde olmuştur.

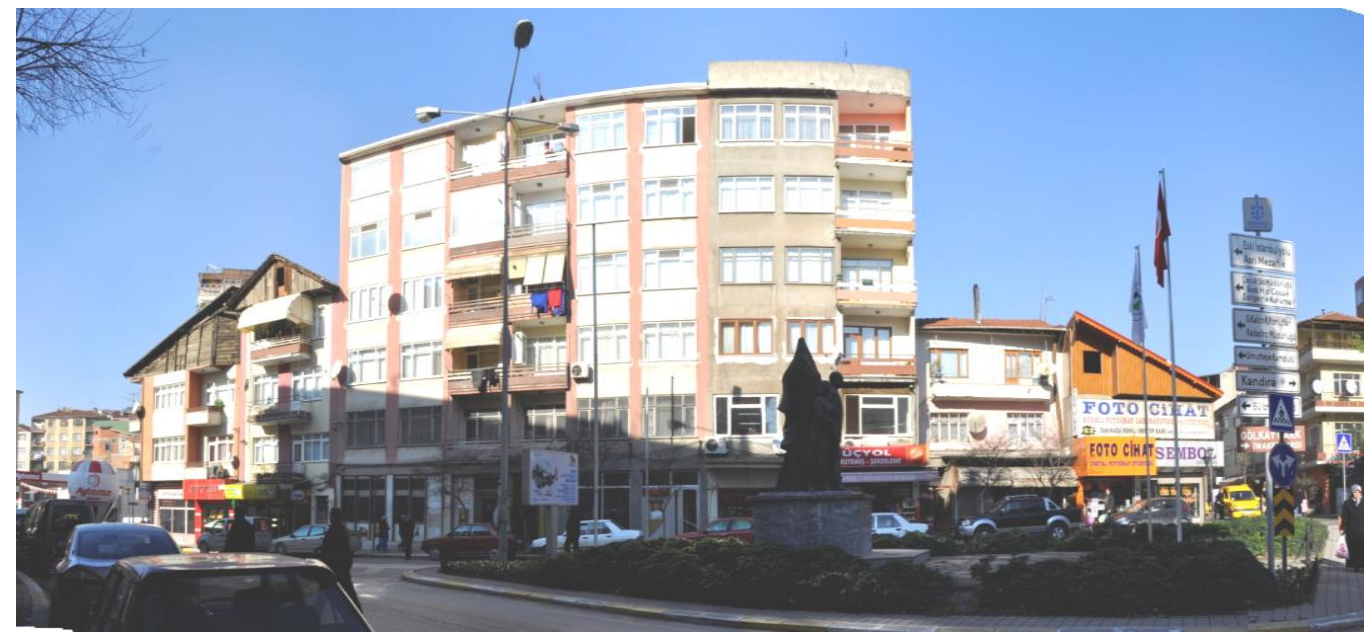

Resim 9. Projenin uygulaması yapılmadan önce Bekirpaşa kavşağının ve kavşağın ortasında bulunan Atatürk heykelinin genel durumu [15] (Figure 10. General situation of Bekirpaşa crossroad and the Atatürk statue located in the middle of the crossroad before the application of the Project [15]

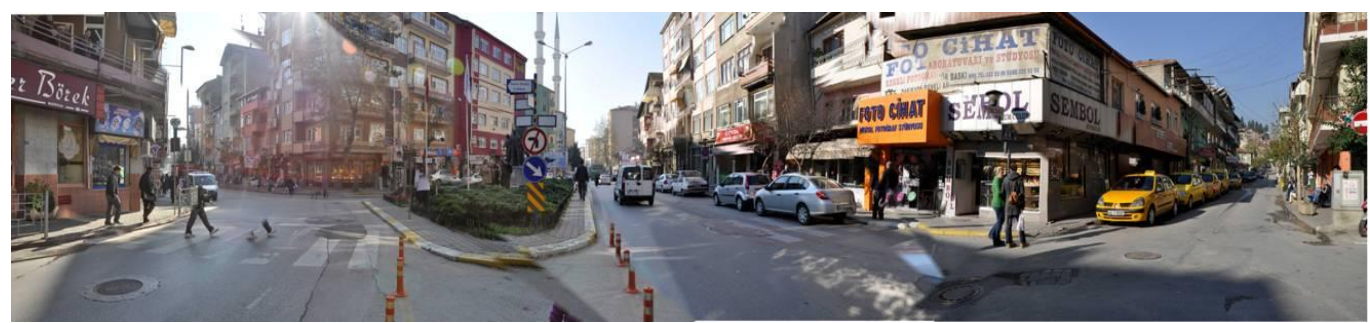

Resim 10. Projenin uygulaması yapılmadan önce Bekirpaşa kavşağına bağlanan sokakların genel durumu [15]

(Figure 11. General situation of the streets connecting to Bekirpaşa crossroad before the application of the project [15]

Bu tespitler ile yola çıkılarak yapılan değerlendirmeler ve yerel yönetimin ilgili birimlerinin sağladıkları veriler ışığında üretilen projede; mevcut görüntü kirliliğini perdelemek, yaya 
kullanıcıları alanda bulundukları zamanda atmosfer etkilerinden kısmen korumak, yaya kaldırımlarını daha kullanışlı hale getirmek amacı ile 5 metre aks aralıkları ile tente eklentili bir arkad sistemi düşünülmüştür. Alanın kullanımı sırasında ihtiyaç duyulacak tüm kent mobilyalarının eklemlenmesi için de bu sistem değerlendirilmiştir. Ayrıca, bu arkad sistemi meydan alanının sınırlarının tanımlanması aşamasında da etkili bir öğe olarak kullanılmıştır. Kent yaşamının gereklerinden olan bilgi, belge paylaşım etkinlikleri ya da sosyalkültürel içerikli etkinliklerde kapalı alan ihtiyacı için, genişletilen kaldırımlarda yarı açık bir hacim yaratılması amaçlanmıştır. Bu hacim, alanın bütününde düşünülen arkad sisteminin eylem için seçilen alanda tekrarı ile çözüm üretilmiştir.

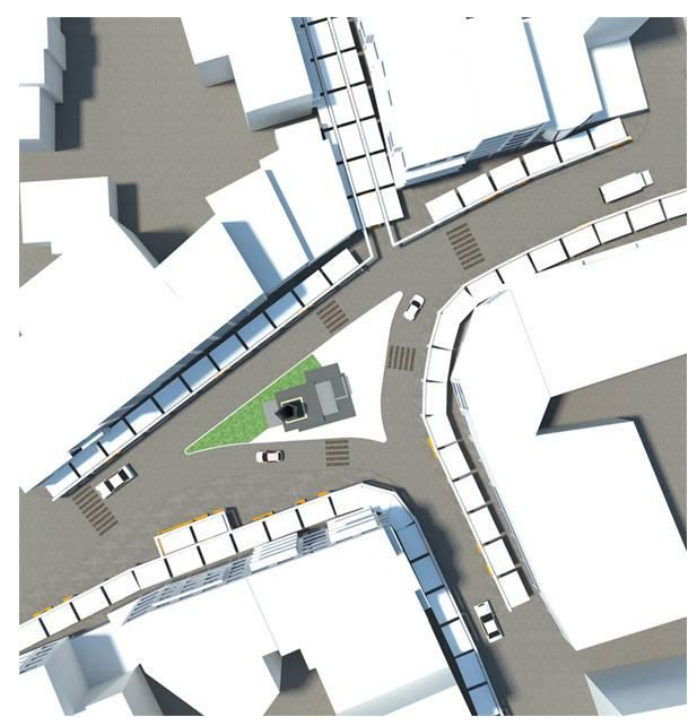

Resim 11. Üçyol Meydanı projelendirme çalışmasının vaziyet planı [15] (Figure 12. Layout plan of Üçyol Square's project designing works [15]

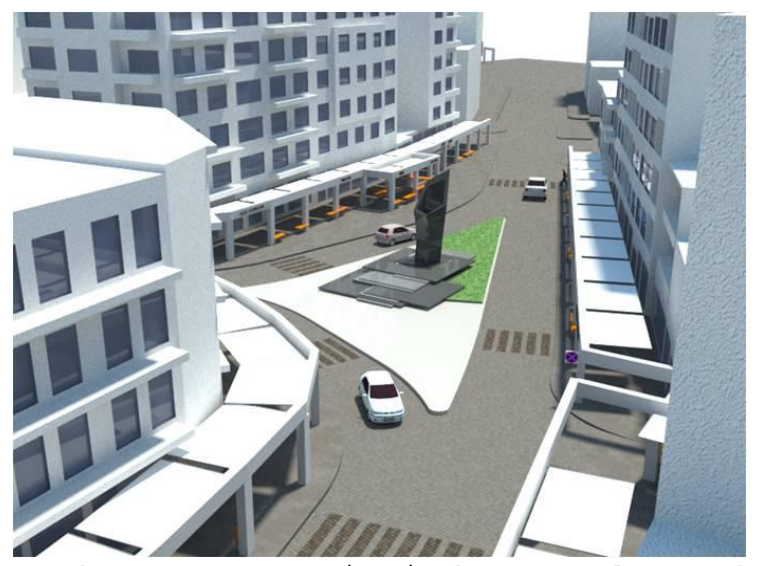

Resim 12. Üçyol Meydanı avan projesinde tasarlanan kavşak noktası ve Atatürk heykeli kaidesinin tasarımı [15]

(Figure 13. Crossroad point designed in Üçyol square concept project and design of Atatürk statue [15]

Meydana bağlanan yollardan biri olan Özkan Sokak'taki taksi durağı, erkek berberleri ve çay ocakları esnaflarının sokağı kullanım alışkanlıkları dikkate alınarak, sokağın aktif trafiğe kapatılması uygun görülmüştür. Yapılan arkad sistemi ile bu sokak için açık alan oturma ihtiyacının mekânsal tanımlamaları tamamlanmıştır. 


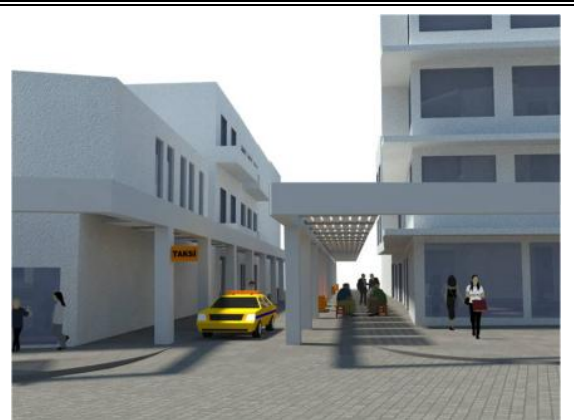

Resim 13. Meydan alanına çıkan ve aktif araç trafiğine kapatılarak yayalaştırılan Özkan Sokak'ın projelendirilmiş durumu [15]

(Figure 14. The project designed situation of Özkan Sokak which leads to the square area and which is pedestrianized upon being closed to the active vehicle traffic [15]

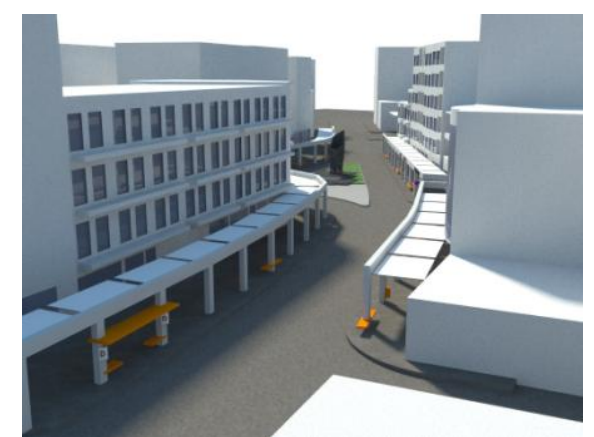

Resim 14. Arkadların kent mobilyası ihtiyacını karşılamada otobüs dură̆ı saçă̆ı, oturma elemanı, gölgelik, bildirim panoları gibi çok eylemli durumunu gösterir görsel çalışmaları [15]

(Figure 15. Visual work displaying multi action situation such as bus stop overhang, sitting unit, shade, notification board for the urban furniture need of arkads [15]

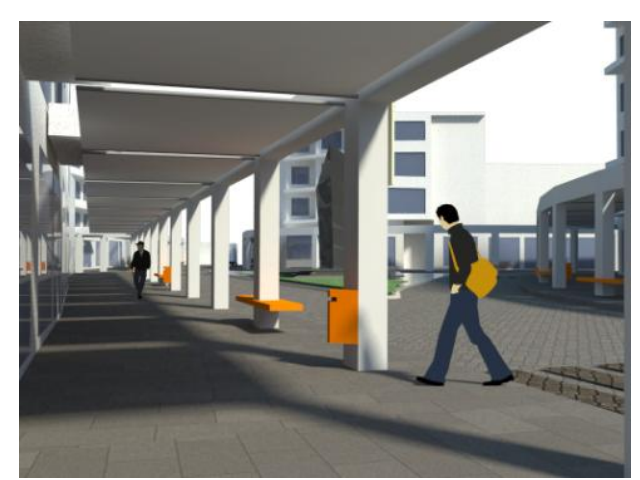

Resim 15. Meydanın sınırlarını belli eden arkad sistemine eklemlenmiş olan kent mobilyalarının kullanıcı ile ilişkisini gösterir sunum [15]

(Figure 16. The presentation displaying the connection between the urban furniture joined to the arkad system showing the square borders and the users [15]

Meydan alanının tanımlanmasının yanı sıra alanın en büyük sorunlarından biri olan görüntü kirliliğine çözüm olarak düşünülen arkad sistemi, üzerinde kent mobilyalarından biri olan dükkan tabelalarını da taşıma görevini üstlenmiştir. Algıda seçicilik ve uzak mesafelerden de okunabilirlik gibi koşullar dikkate alınarak amaca uygun tek tip malzeme ve boyut ile tabelalara standart biçim getirilmiştir. 


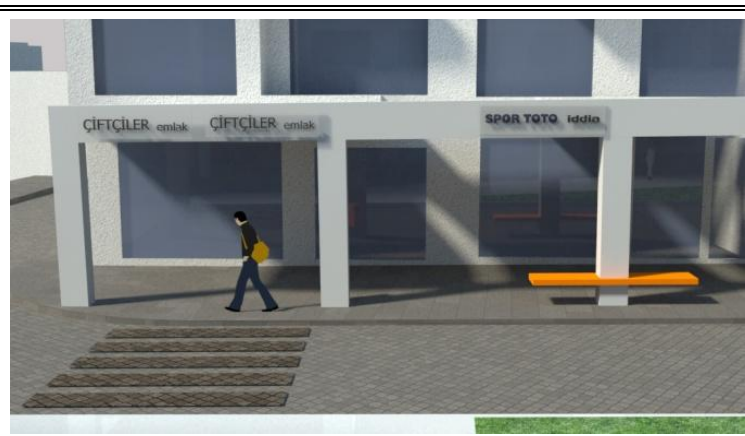

Resim 16. Dükkan tabelalarının tek bir dilde anlatım ile yorumu ve kullanıcı ile ilişkisi [15]

(Figure 17. The interpretation of the shop signs with single language and its connection with the user [15]

Projenin uygulaması Temmuz 2012'de başlamış ve 210 günde bitirilmesi hedeflenen projenin uygulama aşamasında tasarlanan projeye sadık kalınması ve olası uygulama sorunlarının çözümlenmesi için İzmit Belediyesi'ne danışmanlık hizmeti verilmiştir. 17.Kasım.2012'de düzenlenen törenle resmi açılışı yapılmıştır.

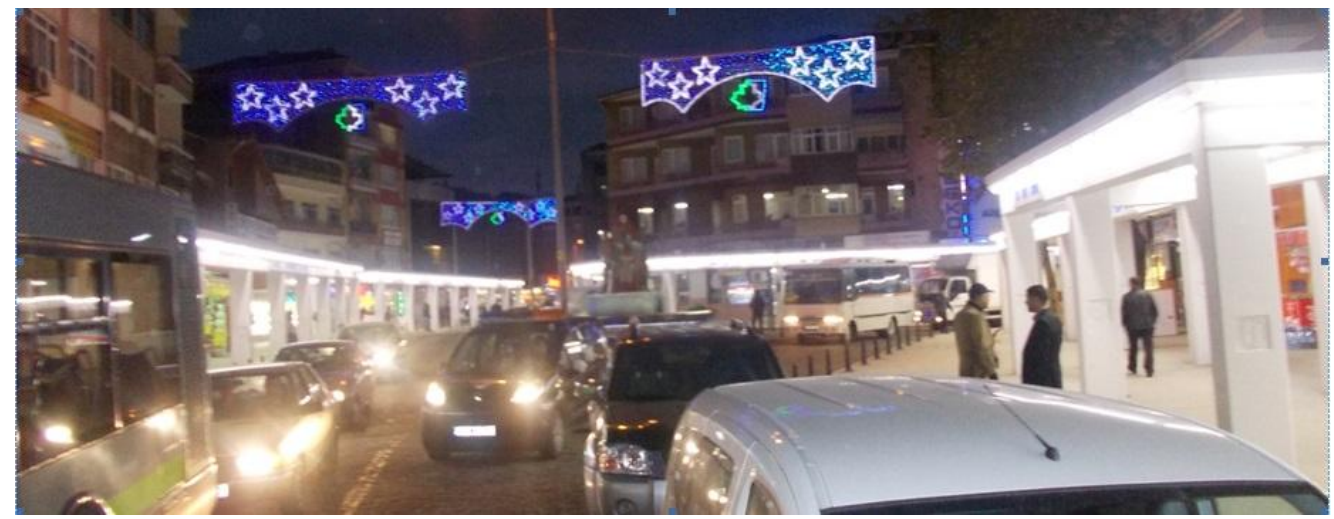

Resim 17. Üçyol Meydanı'nın kullanıma açıldıktan sonraki durumu. (Mart 2013, [16])

(Figure 18. The situation of Üçyol square after bringing into use. (March 2013, [16])

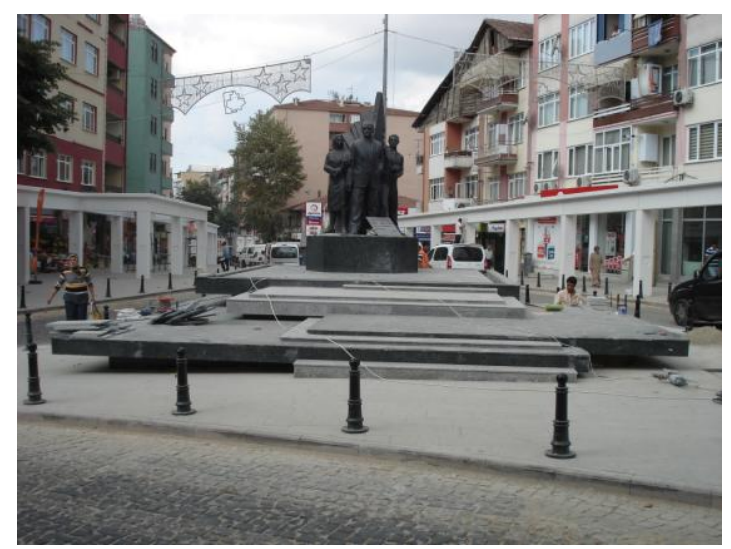

Resim 18. Meydanın odak noktasındaki Atatürk Heykelinin kaidesinin ve çevresinin uygulama sonrası fotoğrafı [16]

(Figure 19. The photo of the surrounding and Atatürk Statue in the focus point of the square after application [16] 


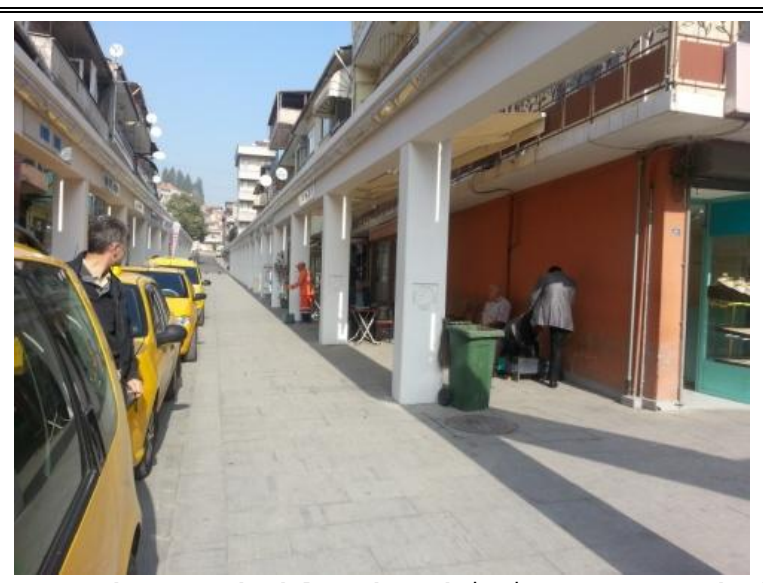

Resim 19. Meydana çıkan sokaklardan biri ve yaya kulıanıcısı yoğun olan Özkan Sokak'ın uygulama sonrası fotoğrafı [16]

(Figure 20. The after application photo of one of the streets leading to the square and Özkan Sokak, heavily occupied with the pedestrians [16]

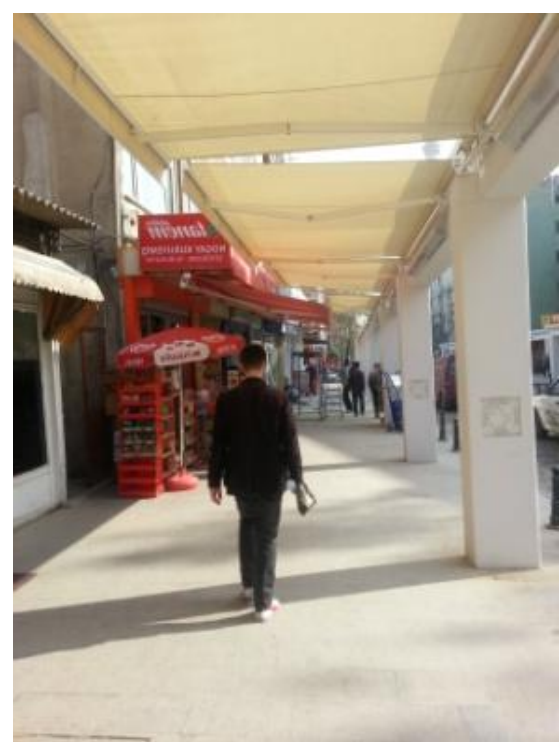

Resim 20. Meydan sınırlarını çizen arkad sisteminin uygulama sonrası fotoğrafı [16]

(Figure 21. The after application photo of arkad system drawing The borders of the square [16]

\section{SONUÇ (CONCLUSION)}

Yapılan bu uygulama, yerel yönetimin talebi üzerine meydanın sorunlarının giderilmesine dair değerlendirildiğinde; tespit edilen sorunlara ilişkin üretilen çözümlerin doğru olduğu sonucuna varılmaktadır. Ancak, kentlerin odak noktaları olan ve kentin nabzını tutan meydanların biçimlenmesine ve anlam değiştirmesine ilişkin değerlendirme yapıldığında, çalışma alanının kendi dinamikleri içinde gelişimini yaparak ülkemizdeki kentleşme sürecinin ortaya çıkardığı, diğer bir deyişle türettiği bir kavşak-meydan olduğu sonucuna varılmaktadır.

Üçyol Meydan uygulaması, içerdiği alanın mevcut dinamiklerini en iyi şekilde karşılayarak ve mevcut geçmişinden gelen izleri takip ederek kullanıcılarına ihtiyaçları olan açık kent mekânlarını ve bu mekânların sağladığı tüm aktiviteleri sağlamaktadır. Ancak, incelenen diğer örneklerdeki gibi geçmişine ilişkin izler ve bilgiler asırlarla 
ifade edilemediğinden alanın merkeziyetçiliğini tanımlayan Atatürk Heykeli ve kullanılan arkad sistemi de bu tanımsızlığa karşı duruş olarak üretilmiş bir tasarımdır.

$$
\text { Sonuç olarak; ülkemizde sanayileşmenin tetiklediği }
$$

yerleşimlerdeki kontrol edilemez hızlarda olan nüfus artışı ve buna bağlı artışı olan araç ve yaya trafiği, öngörülmüş olan yol ağlarına bir süre sonunda sığmaz hale gelince mekânsal konforsuzluk oluşturmaktadır. Çalışmada anlatılan meydan kavramının da bu konforsuzluk bağlamında çözüm üretimi için devreye girmesine mümkün olmakta ancak; imgeler, kullanıcl istekleri, ihtiyaçları, yasal yükümlülükler ve diğer zorunluluklar sayesinde kuramsal olarak açıklana gelen kavramların içeriklerinin yüzyıllar içerisinde değişiminin ve gelişiminin farkına varılmaktadır. İşte bu bağlamda; Üçyol Meydan Düzenleme Projesi, sanayileşme ve kentleşme faaliyetlerinin biz kentlilere kazandırdığı yol kesişimi olan kavşakların oluşturduğu bir yaya odaklı ancak araç trafiğine de açık, yerel yönetimin de "meydan" olarak isimlendirdiği bir 21. Yy. meydan kurgusu örneği olarak kayıtlara geçmiştir.

\section{NOT (NOTE)}

Bu çalışmaya konu olan "Üçyol Meydan Düzenleme Projesi", İzmit Belediyesi'nin Kocaeli Üniversitesi Mimarlık ve Tasarım Fakültesi'nden 15.10.2010 tarih ve 4063 sayılı talebi üzerine, Dekanlık makamı üzerinden yapılan görevlendirmeler ile avan proje olarak hazırlanmıştır. Projenin uygulama aşamasında danışmanlık görevi devam etmiş ve projenin uygulaması 16.11.2012 tarihinde tamamlanarak alan kulıanıma açılmıştır. Avan proje hazırlanırken fotoğraflama, tasarım ve sunum çıktılarının hazırlanması gibi süreçlerde ve projenin uygulama aşamasındaki danışmanlık hizmeti sırasında; Y.Doç.Dr. Didem ERTEN BILGİÇ, Y.DOÇ.Dr. E. Yeşim ÖZGEN KÖSTEN, Y.DoÇ.Dr. Özgü ÖZTURAN, Y.Doç.Dr. Bülent AYBERK, Öğr.Gör. Ahmet ÇAĞLAYAN ve Arş.Gör. Gülhis DUYGUN, Arş.Gör. İrem USLU görev almıştır. Çalışmaya konu olan "Üçyol Meydan Projesi", adı geçen kişilerin oluşturduğu çalışma grubunun ortak ürünüdür.

\section{TEŞEKKÜR (THANKS TO)}

Üçyol meydan düzenlemesi avan projesinin üretimi aşamasında güçlü bir iletişim ağı kurup bu sayede bu projenin kısa sürede amacına uygun olarak üretilmesini sağlayan İzmit Belediyesi'nin ilgili birimlerine, çalışma arkadaşlarıma ve desteklerini bizden esirgemeyen Üniversiteme; ayrıca bu çalışmanın yayına dönüşmesi konusunda beni teşvik eden saygıdeğer Hocam Prof.Dr. Kamuran Öztekin'e teşekkür ederim.

\section{KAYNAKLAR (REFERENCES)}

1. Dağıstanlı, Ö., (2007). Meydanın Evrimi, Mekansal Analizi ve Sosyal Açıdan Önemi, Yayınlanmamış Yüksek Lisans tezi, İTÜ, s.12

2. Erdoğan, E., (1996). Anadolu Avluları Özellik ve Düzenleme İlkeleri Üzerinde Karşılaştırmalı Bir Araştırma, Ankara Ün., Fen Bil. Ens., Peysaj Mimarlığı Ana Bilim Dalı, Basılmamış Doktora Tezi, s. 547.

3. Vardar, A., (2005). "Meydansız Kentler", Şehir Plancıları Odası, Planlama Dergisi, Sayı: 3, s.30-41.

4. Yiğit Malkoç, E. ve Türel Sönmez, H., (2006). İlkçağlardan Günümüze Anadolu'da Açık Mekanın Evrimi. Tekirdağ Ziraat Fakültesi Dergisi, Journal of Tekirdag Agricultural Faculty, Cilt: 3, Sayı: 2, s. 187-195. 
5. İnceoğlu, M., (2013). Sivrihisar'da Sürdürülebilirlik Üzerine Üç Mimari Proje. NWSA Social Sciences, Cilt: 8, Sayı: 3, ISSN: 1306-3111/1308-7444, DOI:http://dx.doi.org/10.12739/NWSA.2013.8.3.3C0114

6. http://cbs.kocaeli.bel.tr/sehirrehberi_silver/ izlenme tarihi: 15.06.2013 üzerinden yapılan çalışma.

7. http://webarsiv.hurriyet.com.tr/2005/09/02/695973.asp 02.09.2005 tarihli Hürriyet Gazetesi Cuma eki. izlenme tarihi: 25.06.2013

8. http://webgis.izmit.bel.tr/netcadsilvermap/page.aspx?Ws=REHBER izlenme tarihi: 15.06.2013 üzerinden hazırlanmış sunum.

9. http://www.asiklihoyuk.org/AHtur.html İzlenme tarihi: 26.07 .2013

10. http://www. flickr.com/search/?q=piazza20del\%20 campidoglio izlenme tarihi: 15.07.2013

11. http://www.flickr.com/search/?q=neuf\%20brisach\%20 izlenme tarihi: 15.07.2013

12. http://dergiler.ankara.edu.tr/dergiler/18/38/320.pdf Kaya, M., (2007). XIX. Yüzyılda İzmit (Kocaili) Sancağı'nın Demografik Durumu ve İskan Siyaseti, Tarih Araştırmaları Dergisi s. 60-61, izlenme tarihi: 05.05.2013.

13. http://www.kafkasakademi.com/haberler/kocaeli-de-tarihselgocler-335.html Ulugün F. Y., (2012). Kocaeli'ye Tarihsel Göçler, Kafkas Akademi, izlenme tarihi: 05.05.2013.

14. http://www. yerelnet.org.tr/belediyeler/belediye_album.php?albumk od=12621\&belediyeid=129840 izlenme tarihi: $02.1 \overline{0} .2013$.

15. Kocaeli Üniversitesi, Mimarlık ve Tasarım Fakültesi, Bekirdere Üçyol Proje Atölyesi Arşivi, 2010.

16. Didem ERTEN BILGİ̧ arşivi,2010.

17. Didem ERTEN BİLĠÇ arşivi,2013. 